\title{
Work Attitudes and Union Membership
}

\begin{abstract}
Clerical workers of two unionized academic libraries (the University of Pennsylvania and Drexel University) were surveyed in an attempt to relate specific work and union attitudes. Elements considered included sex, age, education, job satisfaction, and union activism. The study also compares the previous union attitudes of the workers with their attitudes after their union experience.
\end{abstract}

\section{BACKGROUND FOR THE STUDY}

$\mathrm{T}$ HE PROBLEM OF UNIONIZATION IN LIBRARIES has been given increasing attention in library literature in recent years. Naturally enough, this attention has focused on the librarian caught in the dilemma between the ideals of the professional organization and the proven effectiveness of the labor union. Less attention has been paid to the unionization of the nonprofessional staff of the library. Yet the continued growth and success of clerical and public service unions guarantee that an increasing number of future librarians will find themselves working in union situations whether or not they are members themselves.

Few textbooks in library administration so much as acknowledge the existence of unions, and there is little in the library school curriculum which would adequately prepare a librarian to deal with them. Yet within a library system which has a unionized clerical staff, it is at the very lowest levels of adminis-

Michael J. Simonds is a member of the staff of the University of Pennsylvania Libraries, Philadelphia. This article is based on a paper prepared while the author was a student in the Graduate School of Library Science, Drexel University. tration where the inexperienced librarian must deal on a day-to-day basis with the union, supervising the department or section within the context of a formal union contract. Here the librarian must quickly become acquainted with the contract provisions and language, management rights, grievance procedures, and detailed, formalized job descriptions. If it achieved nothing more than to familiarize the librarian with the ideas and attitudes of the clerical worker, research in this area would be more than justified.

But perhaps we can ask for even more; in a systematic study of work and union attitudes among clerical employees we might also find some answers relevant to the dilemma of the librarian. Why do people join unions? Which union benefits do people consider most important? Which aspects of unionization do union members themselves find most distasteful? Is a person more likely to support a union if he is dissatisfied with his job or his supervisor? Once a union has been established and has found a working relationship with the library does it promote employee loyalty to the library? Or is there something inherent in the bargaining process that inevitably entails a certain degree of employee-administration alienation? It is questions such as these that this study will attempt to probe. 


\section{The Study}

A questionnaire on work attitudes and union membership was given to clerical employees of the University of Pennsylvania and Drexel University libraries. The questionnaires were developed from a series of interviews conducted at Drexel University in January 1973. The questionnaires were as close to being identical as the individual situation of each institution would allow.

Local 590 of the American Federation of State, County, and Municipal Employees (AFSCME) represents the clerical workers at the University of Pennsylvania library system. All of the clerical employees of Drexel University are represented by Local 2481 of AFSCME, not just those in the library system as is the case with Penn. Situated a few blocks apart, the libraries of the two schools have worked closely together, and plans call for an even greater degree of cooperation in the future. A capsule history of the two union locals is presented, for it is in the contrast between them that some of the most relevant conclusions may be found.

\section{The University of Pennsylvania and Local 590}

Local 590 was formed as a result of elections held by the National Labor Relations Board in February 1969. In that election the union received approximately two-thirds of the votes cast and won the right to represent all nonprofessional members of the university's library system. The local negotiated its first contract in the summer of 1969 , followed by a two-year contract in 1970, another one-year pact in 1972, and a fourth contract starting on May 1, 1973, effective for eighteen months.

These four successful contracts represent a rise in the base salary rate of over $\$ 2,600$ a year, along with many other benefits which are all but unprecedented for unions of this type. All of this was accomplished at the bargaining table. Local 590 did not strike the University of Pennsylvania, although it did support a four-day strike by the cafeteria workers in May 1971.

During the four and one-half years Penn has been organized, both the union and the administration have learned to adjust to the situation. The library administration now regularly holds seminars for its department heads to explain provisions of the contract and other subtleties of the collective bargaining process. Similarly, the union holds monthly meetings for its shop stewards to keep them informed on union business and to discuss problems arising in their respective work units.

On occasion, such as a meeting dealing with the implementation of a new medical plan, the administration called together the officers and stewards of the union to explain fully some new plan or program so that the stewards might in turn carry the explanation to their respective work units. Thus, in effect, the university made use of the union as a channel of communication to its own employees. There is here then an example of a library administration and a union that have learned to live together, if not in harmony, at least managing to avoid most of the destructive cross-currents so familiar in labor relations.

\section{Drexel University and Local 2481}

The nonprofessional union at Drexel University is of much more recent origin than the Penn union, and indeed it was largely inspired by the success gained by Local 590 at Penn. An NLRB election, held in 1972 at Drexel, was won by the union with a vote of 134 to 121 , with sixty employees not voting.

Negotiations for the first contract were terminated and reopened a number of times before a federal mediator was called in. When his efforts failed to bring about a settlement, the union struck the university; the strike lasted 
a little less than two weeks before an agreement was reached. The tension from the strike had only begun to subside when the university discharged the head of the library reference department, a long-time professional member of the Drexel staff who had refused on principle to cross the picket line during the strike. This action was upheld despite numerous protests, including a petition from 587 faculty and students.

Before this matter was settled, however, it was overshadowed by a strike of Drexel maintenance workers. Although they had just been through a strike of their own, most of the members of Local 2481 supported the strike. At the end of the first two months of the strike, however, only a handful of clerical workers remained out. The university terminated the services of all those who had not returned to work. Among the fifteen people who lost their jobs in this way were the president, vice-president, secretary, treasurer, and two executive board members of the union, as well as two union stewards. With these people removed from the bargaining unit, the local was semileaderless during the critical period of adjustment under the new contract.

The situation of Local 2481 then at the time of this survey was unusual: Negotiations for a new contract were about to begin although several members of the negotiating team were no longer officially employed by the university. All fifteen terminated members were at various stages of judicial proceedings against the university to regain their positions. (After the survey reported here was completed, Local 2481 lost a decertification election, June 1973 , and thus no longer represents the employees at Drexel.)

The two unions at Penn and Drexel present the contrast between a stable, established, functioning union and one caught in the trauma of conflict and frustration. It is to be hoped that the results of this contrast will, in some meaningful way, cast light on the problems under consideration.

\section{Mechanics of the Study}

It was the aim of this study to survey by questionnaire all current classified nonprofessional employees of both the Penn and Drexel libraries.

At Penn a total of 163 persons were members of Local 590 at the time of this survey. Every effort was made to reach the entire membership. A total of 99 people responded for a return rate of 60.7 percent. At Drexel University twenty-three returns from the fortyeight nonprofessionals gave a return rate of 47.9 percent. It must also be noted that there is a bias built into the Drexel sample in that none of the 15 people terminated by the university could be included in the survey. Technically they are no longer employees of the university, and yet they represent the core of union activism at Drexel.

Because of these factors, a higher level of confidence can be placed in the Penn findings than those of Drexel. For this reason, the major part of the survey will rely on the data from Penn. The results from Drexel will be used in a later section, mainly for the purposes of comparison. While every effort was made to achieve the highest standards of reliability and validity in the instrument used and in the processing of the results obtained, all results must be advanced tentatively and only within the limited framework of the stated goals of this paper.

\section{The Results: University of Pennsylvania}

The ninety-nine respondents from Penn included sixty-four women and thirty-two men, a ratio not uncommon in the library world. (Three questionnaires were returned without the sex of the respondent being specified.) As for age, 33 percent of the respondents were 
TABLE 1

Job Satisfaction, University of Pennsylvania

\begin{tabular}{lcccccr}
\hline \hline \multicolumn{1}{c}{ Job Satisfaction } & Male & Sex & Female & $20-25$ & $26-30$ & Age \\
\hline Job Interesting & $32.4 \%$ & $34.9 \%$ & $24.3 \%$ & $28.1 \%$ & $51.6 \%$ & Total \\
Job Mildly Interesting & 38.2 & 34.9 & 30.3 & 31.3 & 42.0 & 34.5 \\
Job Just Okay & 17.7 & 23.8 & 33.3 & 28.1 & 3.2 & 21.6 \\
Job Dull and Repetitive & 8.8 & 3.2 & 9.1 & 9.4 & 0.0 & 6.2 \\
Job a Real Pain & 2.9 & 3.2 & 3.0 & 3.1 & 3.2 & 3.2 \\
\hline
\end{tabular}

twenty to twenty-five years old, 32 percent twenty-six to thirty, and the remainder thirty-one years old and older. In terms of educational background, 40 percent had at least two years of college, another 24 percent had three to four years of college. Twelve percent of the respondents had completed some graduate work, and 24 percent had some graduate studies in librarianship.

\section{Work Attitudes}

Questions were asked Penn employees concerning work attitudes-their job satisfaction, job complaints, and opinions about their supervisors. Table 1 gives answers to the basic question of job satisfaction.

The most obvious fact from Table 1 is how dramatically job satisfaction increases with age. The young are far less likely to be happy with their jobs than those over thirty who scored a surprising 93 percent.

This same phenomenon can be seen in the rating of supervisors (Table 2). Again it is the young who rate their supervisors more severely, though the difference here is somewhat less than in Table 1.

Yet age alone is not the only deter- mining factor in job satisfaction. One of the other major factors was found to be education, as shown in Table 3 . Here it was found that fully 82 percent of the library science students and 89.4 percent of those with one or two years of college felt their jobs were at least mildly interesting. This compares with only 54 percent of those with three to four years of college and 58 percent of those in graduate school.

Perhaps this can be accounted for by the higher job expectations of those groups with a college degree or more. Library science students are exceptions to this trend, but they are working in their chosen career field.

Another significant factor in job satisfaction turned out to be the relationship between the employee and the supervisor. When asked if they felt their supervisors were sympathetic to their job problems, 90.6 percent of those with the highest job satisfaction answered affirmatively. Of those who felt their jobs were just "mildly interesting," 64.7 percent felt their supervisors were sympathetic. With the "Just Okay" group, this score fell to 54.4 percent while those that chose one of the two negative responses had a score of only 44.4 per-

TABLE 2

Supervisor Rating, University of Pennsylvania

\begin{tabular}{|c|c|c|c|c|c|c|}
\hline \multirow[b]{2}{*}{ Supervisor Rating } & \multirow[b]{2}{*}{ Male } & Sex & \multirow[b]{2}{*}{$20-25$} & \multicolumn{2}{|c|}{ Age } & \multirow[b]{2}{*}{ Total } \\
\hline & & Female & & $26-30$ & $31+$ & \\
\hline Excellent & $36.4 \%$ & $31.7 \%$ & $39.3 \%$ & $25.0 \%$ & $35.3 \%$ & $33.3 \%$ \\
\hline Good & 33.3 & 38.1 & 30.3 & 37.5 & 41.2 & 36.4 \\
\hline Fair & 18.2 & 15.9 & 15.2 & 18.75 & 17.6 & 17.2 \\
\hline Poor & 12.1 & 14.3 & 15.2 & 18.75 & 5.9 & 13.1 \\
\hline
\end{tabular}


TABLE 3

Education and Job Satisfaction, Universtry of Pennsylvania

\begin{tabular}{lccccc}
\hline \hline & & \multicolumn{5}{c}{ Amount of Education } \\
Job Rating & High School & 1-2 College & 3-4 College & Grad & Library Science \\
\hline Job Interesting & $40.0 \%$ & $52.6 \%$ & $16.7 \%$ & $16.7 \%$ & $43.5 \%$ \\
Job Mildly Interesting & 25.0 & 36.8 & 37.5 & 41.7 & 39.1 \\
Job Just Okay & 20.0 & 5.3 & 33.3 & 33.3 & 17.4 \\
Job Dull and Repetitive & 15.0 & 5.3 & 4.2 & 8.3 & 0.0 \\
Job a Real Pain & 0.0 & 0.0 & 8.3 & 0.0 & 0.0 \\
\hline
\end{tabular}

cent. The most common complaint given by the employees was about the nature of the work itself (filing, typing, etc.), and this irritation was felt most frequently by the young. The second most common complaint was about the quality or type of supervision, and this was felt across age and sex lines as was a third complaint about the catchall of "administrative inflexibility."

\section{Union Attitudes}

Attitudes and opinions of the Penn employees toward their union were also explored. The most basic question was how many would join the union if it were a matter of choice? (Penn has a union shop.) More than 80 percent indicated they would join.

Given this rather impressive majority, it is interesting to ask what attitudes the Penn employees had about unions before they came to work at Penn. Table 4 presents some striking differences, first of all between men and women. Seventy percent of the men had a positive attitude toward unions previous to their Penn experience as opposed to only 33.8 percent of the women. Ten times as many women as men had simply never thought much about unions. Interestingly, of the members of the library science group, only 15 percent had favorable union attitudes as opposed to the sample's average of 45.3 percent.

In the answer to a subsequent question on the reason for the previous attitude, the most common reason given for a very high opinion of unions was prior personal experience. The most frequent reasons for a low opinion were the mass media and the prior experience of friends or relatives. The respondents indicated overwhelmingly (78.6 percent) that as a result of their experience at Penn their attitude toward unions had become more favorable. Three major factors were mentioned for this change in attitude: pay benefits, job security, and medical benefits.

Major irritants about the union were the lack of individual merit in consideration for job advancement under union rules, the problems involved in supporting other people's strikes, and the possibility of a strike threat every year.

The Results: Drexel

The total number of respondents for

TABLE 4

Previous Union Attitude, University of Pennsylvania

\begin{tabular}{lcccccccr}
\hline \hline & \multicolumn{2}{c}{ Sex } & \multicolumn{7}{c}{ Amount of Education } \\
& Male & Female & School & College & $\begin{array}{c}\text { Library } \\
\text { College }\end{array}$ & Grad & Science & Total \\
\hline Favorable & $40.0 \%$ & $17.7 \%$ & $31.5 \%$ & $17.6 \%$ & $34.8 \%$ & $30.7 \%$ & $15.0 \%$ & $23.7 \%$ \\
Mildly Favorable & 30.0 & 16.1 & 15.7 & 47.2 & 17.4 & 30.7 & 0.0 & 21.6 \\
Never Cared & 3.3 & 33.9 & 31.5 & 5.8 & 17.4 & 7.7 & 40.0 & 22.7 \\
Unfavorable & 20.0 & 27.4 & 21.3 & 23.6 & 26.0 & 7.7 & 35.0 & 25.8 \\
Highly Unfavorable & 6.7 & 4.9 & 0.0 & 5.8 & 4.4 & 23.2 & 10.0 & 6.2 \\
\hline
\end{tabular}


the Drexel library is much smaller than that of Penn, twenty-three as compared to ninety-nine. Thus it is more difficult to make generalizations about any subgroups in the sample. It must be remembered that the Drexel sample excludes the most active union members as these individuals had been discharged prior to the survey.

As at Penn, females outnumber males (thirteen to nine with one respondent not indicating sex); but the Drexel sample is much younger with 60.8 percent of the group in the twenty to twentyfive age group as opposed to the 33.3 percent for Penn.

Local 590 has claimed to have cut the turnover rate at Penn from over 60 percent to about 7 percent annually. Certainly, there is a marked difference between the two samples. At Penn 50.5 percent were employed there more than four years; at Drexel only 17.4 percent.

There were differences, also, in expressions on job satisfaction at the two libraries, and Table 5 presents a summary of the responses.

\section{TABLE 5}

Job Satisfaction, UnIVERSTTY OF PENNSYLVANIA AND DREXEL UNIVERSITY

\begin{tabular}{lcc}
\hline \hline Job Satisfaction & $\begin{array}{c}\text { Penn } \\
(\mathrm{N}=99)\end{array}$ & $\begin{array}{c}\text { Drexel } \\
(\mathrm{N}=23)\end{array}$ \\
\hline Very Interesting & $34.5 \%$ & $17.4 \%$ \\
Mildly Interesting & 34.5 & 47.9 \\
Just Okay & 21.6 & 13.0 \\
Dull and Repetitive & 6.2 & 13.0 \\
A Real Pain & 3.2 & 8.7 \\
\hline
\end{tabular}

At Drexel 65.2 percent of the respondents had joined the union of their own choice, 17.4 percent had begun work after the effective date of the new contract and thus were required to join the union. The remaining 17.4 percent had refused to join the union.

Given the difficult series of events at Drexel, one might question the attitude of the employees toward the university. Asked if the university would be fair to its employees if there were no union, the respondents were closely divided43.4 percent declaring the school fair, 56.6 percent answering not fair. At Penn, however, in answering the same question, 20.8 percent stated the school as fair and 74.2 percent as not fair. (With a union present, however, 57.6 percent of the Penn respondents stated the university is now fair. The change was not so dramatic at Drexel where 54.5 percent of the sample recorded the school as fair given the presence of the union.)

The main job complaint at Drexel, overwhelmingly, was inadequate pay. All respondents felt they were underpaid. At Penn, by contrast, 22.3 percent considered they were underpaid.

Drexel respondents' previous attitudes toward unions were similar to those at Penn, and 43.4 percent recorded favorable or mildly favorable attitudes. At Penn, however, favorable union attitudes were strengthened as reported above; but of the Drexel respondents, only 30.4 percent reported a more favorable attitude following the union experience. Drexel employees' complaints against the union were spread across the board. Naturally enough, "problems involved in supporting other people's strikes" was the most frequently cited complaint, mentioned by fully 74 percent of those responding. But also frequently mentioned were such factors as "lack of communication between leadership and union" (43.5 percent) and "lack of effective leadership" (39.1 percent).

As at Penn, pay benefits were the most often mentioned advantage of union membership. Medical and education benefits were also cited, although the latter was mentioned more frequently by nonunion than union members.

\section{Summary and Conclusions}

The most definite finding from this survey was the central role of wage and 
salary benefits in any consideration of union attitudes at either school. The employees at Penn recognized their wage benefits as the most central and important success of their union. Although 77.8 percent of the Penn employees indicated at the time of the survey that they were at least adequately paid, the fact that they were aware that this condition was the result of the success of their own local was seen in the overwhelming response to the answer on union benefits which mentioned wages and salaries almost twice as often as all other benefits combined.

Both education and age were factors related to job satisfaction. The presence of a sympathetic supervisor was also strongly related with job satisfaction. The least satisfied employees were the young, and their most frequent complaint was the nature of the work itself.

Union members do seem to be less satisfied with their jobs than nonunion members or those who would not be union members if they had a choice. However, it must not be overlooked that while their job satisfaction was lower than the antiunion group, a majority (65 percent) of union members did have a positive response toward their jobs.

The questions on previous union attitudes could not have been encouraging to the union organizer. The dramatically more negative attitude of women than men on this question seemed especially relevant given the usually high ratio of women to men in most libraries. The only encouraging factor here is that most women may simply not have thought much about unions, and their opinions may be based on images from the mass media. Such opinions are subject to change given a degree of practical success by the union as was shown in the Penn sample where 81 percent of the women were now more favorable towards unions as a result of their experience.
Such may not be the case with professional librarians. In our sample library science students had the most negative previous union attitudes of any educational group. Just as importantly these negative attitudes may more likely be based on philosophical considerations than other groups and, therefore, less subject to change as the result of practical success on the part of the union. Although a solid majority of this group (63.6 percent) now support the union, this still compares unfavorably with the 83 percent support from the employees at Penn as a whole. In short, it is not impossible to win over even the professionally oriented employee; but they may be the toughest group the union has to deal with.

It also appeared as if it is the union which receives either the credit or the blame for the employee's welfare. Where successful, the union receives full credit; and the administration is still perceived with mistrust. Where success is limited, it is the union leadership which takes the blame, apparently regardless of the policies pursued by the administration. Given the fact that only two unions in very different situations were studied, this conclusion must be very tentatively advanced. It would be interesting to see if this finding holds up with other unions in the same field, or whether certain styles of leadership are able to overcome a lack of immediate practical success while building an effective organization.

Lastly, it does not appear that any large degree of union-management conflict can take place without that conflict being reflected to some degree by bitter divisions among the employees and thus the union membership itself. Most labor wars are in part civil wars, and the problem which confronts the union leadership is how to deal with an administration in an adversary relationship without alienating a large part of its own less than enthusiastic members. 